\title{
Talent Management
}

\author{
Al Mutairi Aned O. ${ }^{1}$, Siti Rohaida Mohamed Zainal ${ }^{2} \&$ Al Mutairi Alya O. ${ }^{1}$ \\ 1 School of Mathematical Sciences, Universiti Sains Malaysia, Penang, Malaysia \\ 2 School of Management, Universiti Sains Malaysia, Penang, Malaysia \\ Correspondence: Al Mutairi Aned O., School of Mathematical Sciences, Universiti Sains Malaysia, Penang, \\ Malaysia.E-mail: nomasss@hotmail.com
}

Received: April 29, 2013

Accepted: May 16, $2013 \quad$ Online Published: November 18, 2013

doi:10.5539/jms.v3n4p110

URL: http://dx.doi.org/10.5539/jms.v3n4p110

\begin{abstract}
The study is set in context of the issues faced by the financial sector corporations in managing the talent and human capital within their company. Present HRM policies needs to be revised in order to utilize their cash in developing and enhancing talent within the company. The paper is drafted to formulate an investment plan for the financial companies that will facilitate them in introducing a structured talent management program focusing on tangible and intangible returns associated. The strategies defined in the paper are not costly yet possess potentials of attracting the competent and skilled workforce in this industry. The strategies discussed include comprehensive learning through e-learning, experimental learning approach, performance measurement system, rewards and recognition and continuous monitoring of talent management framework. It is expected that these can help in dealing with the complexities within the nature of finance industry too.
\end{abstract}

Keywords: human capital management, talent management, investment plan, performance management

\section{Introduction}

In this globalized and modern era, financial industry is a key point under the global debate to help it in recovering from the global recession. Modern operation features as well as perceptive self-service skills in the financial industry have now become an integral part of the business requiring the strategic business management to re-route their HRM policies in order to develop and maintain workforce talent with reference to the dealing with ever changing requirements of financial regulations. Talent management is somehow similar to the human capital management where recognition and growth of company's talented people is given a high edge by the organizations' management in order to improve the overall efficiency of company.

A discrepancy that could be found in the management of human capital and talent management can be seen in different context. It relates to the fact that TM is associated with the presence of quality of workforce maintained through rewards, recognition and performance management while HCM is annexed with the recruitment of skilled individuals those who see people as an asset of the company whose current value can be determined and whose future value can be improved by means of investment. It is a big issue in today's' business world to integrate tangible and intangible assets of the company in order to produce expected rate of returns from the available portion of cash and investment. It is a worth noting point that in the global society where a strong weight is given to competition, financial return and viability of the business, it is quite necessary to correlate the relationship between cash flow, investment plan and resulting returns from that investment. In other words, ways for monetizing the human capital to increase talent is worth importance.

\section{Cash Flows, Investment Plan and Expected Return on Management of Human Capital's Talent}

Human resource is a tangible asset of the business organization while investment made by the business corporations for the management of talent is the intangible assets. Returns gathered by the company in this context are also an intangible aspect of the business. Past researches have emphasized upon the importance of finance functions to enable employees in producing excellent results throughout the process of tackling enhanced product complexity, unparalleled market steadiness, and ever changing regulations. It has been one of the key strategies of the organizations to hire top talents from the financial competitors with an expectation of similar return. Therefore, in order to integrate the talented individuals for a drive towards success, management of the company is required to make cash investments through a proper investment plan for gaining high-anticipated outcomes. 


\section{Investment Plan for Talent Management in Financial Institutions}

Different business research analysts have defined term "Talent" in different ways. According to Harris, et al. (2012), talent with reference to financial sector is set of skills and competencies necessary for the delivery of company's goals and objectives. After identifying the needs for managing talent within the financial industry, a problem needing investigations relates to the ways that can be adopted for managing the capable individuals in the financial institutions.

\section{Comprehensive Learning through E-Learning}

Big financial organizations accumulate sufficient amount of cash capital that can be used by them for enhancing learning capabilities of the individuals. Comprehensive range of learning can be provided through e learning where management uses its cash flows by devising online finance portals. These portals are helpful in accessibility of management tools, research and benchmarking practices. It is very important for a company to analyze the nature of its business before integrating e-learning tools. E-learning methods can include the use of several media like text, audio, video and other technological applications, processes and other computer based learning platforms. Similarly, now day beneficial edge available to the employees of organization relates to the fact that E-learning might take place within and outside the classroom. However, for a well-established financial institution, E-learning is more worth of investment in order to aid employees enhancing their talent trough the self-paced learning environment rather than an instructor led one. Accounting for such an investment might result in beneficial or unbeneficial investment. In order to assure the reliability of the e-learning environment plan a cost-benefit analysis is necessary to be carried out.

\section{Experimental Learning}

Experimental learning can also be used by the financial organizations in order to deal with the talent management. It has become a predominantly popular phenomenon with younger finance professionals, and could comprise of different talent management tactics like secondments, job rotation and 'stretch' assignments. In researches, it can be examined that business organizations are explicitly focusing upon the development of virtual finance academies for the provision of a structure for finance training and ensuring uniformity. Experimental learning do not cost too much as it is dependent upon the particular exposures of workforce in the business organizations. Employees can be made engaged in a job by giving them real life experiences about the challenges and opportunities associated with a specific job. In finance industry, where the workforce is already facing the challenges of the economic and social downturn of the economy, giving experiments to workers will result in expected returns on tangible and intangible assets. Thomson, (2007) also defines four different learning styles like diverger, assimilator, accommodations and converger in order to extract true benefits of talent management investment. When the employees are given opportunity to enhance their learning through an experimental learning of accounting programs, they start utilizing their capabilities to give it back to the business for which they are working in terms of huge profit margins and increased sales ratio. Experiments like job rotation, secondments and stretch assignments are based on the decreased costs and potentials for the employees to enhance their skills using extensive range of services.

\section{Performance Measurement}

Performance management in financial sector is very significant in order to deal with the competitive industry. It refers to the tool that is used in developing a culture of accountability within the organization. Financial sector, where services offered are very crucial and decision making process is very complicated, making an investment in the modification of the employee behaviors with regards to the their performance has also become very vital. It can be analyzed that with a slight changes in the employee behavior, financial instructions are highly affected. Therefore, for maximization of human capital contribution in the overall system, processes and management, measurement of the human resource performance is also vital. Performance management is also referred as appraisals to the employees by the management, in which workforce is assessed according to a set benchmarking standard. Appraisal can vary from goal setting to the coaching and counseling. Periodic reviews of performance measurement can aid the employees in relating direct as well as indirect outcomes of their work on the expected returns of the business organizations.

Regular feedback from the management also helps in structuring a highly integrated framework for the business monitoring their progress through formal and informal nature of appraisals. Through this process, an automatic identification of lacking in human capital in accomplishment of goals and objectives become possible. Sense of accountability can be developed among the individuals through this talent management tool devised by the practitioners for the management of human capital. Key performance indictors can be used by the company for the development of suitable parameter for employees' performance industry in financial sector. Rate of 
absenteeism, employee turnover, cost effectiveness to the company, quality and quantity of tasks performed and others has been helping the company in analyzing the areas of loopholes that requires to be concentrated in order to pool up sufficient amount of talent for the company.

\section{Reward and Recognition}

After the global and economic recession of 2007-2009, the real value of rewards has decreased among the people. Employers of the financial industry are also facing severe problems related to the management of high talent base in the company due shortage of critic skills and employees' reluctance in working with a specific employer. In the current literature of human capital management, a major shift in the talent attraction drivers can be recognized. They have changed their HR management by keeping focus on devising strategies in accordance with the employee's view. Gaps can be realized in three different areas when the interest of the employer conflicts with the interest of employees. One of the key variation is the employer's approach to give challenging work to the employees while according to employee, all the work assigned to them should be convenient. Likewise, employee wants vacation and holidays, which is not preferred by the employer as he is always seeking to increase chances of learning new skills for his employees. In order to make a connection between the employers' perspective to look after the financial health of its business by providing flexible working structure to employees, changing facets of reward and recognition helped a lot. Apart from financial and monetary compensations, other intangible factors also place a high influence on the employees' productivity and in boosting their talents. These includes availability of better position, greater job security, improved work life balance, greater career opportunity and more flexible working hours.

Likewise, designing an Employee Value Proposition (EVP) can facilitate the decision-making process of the employers in a much comprehensive way. In talent management, EVP can be defined as the experience offered by the management of organization in increasing the performance and productivity of the employees. Present trend scope can be associated with three areas like development of career opportunities and competency, talent rotation and workforce planning. By provision of recognition ad sense of appreciation, employers are able to manage an adequate talent capable of responding to the changing needs of the international competitive financial sector.

A formalized EVP can integrate basics and advanced features of rewards in generating as well as maintaining competencies in global financial sector. Management of talent must adhere to the requirement of international consistency otherwise there are huge chances that the competitor of the company can snatch away the top talented cream from the industry by providing them similar way of working as required by them.

\section{Continuous Monitoring of Talent Management Framework}

Similarly, like the above-mentioned factors, talent management among the human capital can only be done when the organization's management is constantly monitoring the framework. This can help the company building an external as well as internal talent pool for the company. Internal and external coaches can be hired to monitor constantly the progress of talent level within the company and its benefits in making investment of expected returns. The employers in assuring a measurable return on investment can use different parameters and process. Mechanism of monitoring the talent and performance of human capital in the business organization is also necessary to accommodate a change in the business environment due to non-static nature of the financial industry. Through constant monitoring, management is able to quietly identify and take suitable actions in order to manage diversity.

Sreenivas, (2006) emphasized upon the selection process of monitoring to measure it against the costs incurred to manage talent within the business organizations. In this way calculation of the business led advantages will also come into view, including those arising from the talent management selection strategy. Similarly, when the competency framework of a company is directed towards constant monitoring, guarantee of top recruiters in the firm can be assured. Most business organization identifies evaluation and monitoring of the human capital management framework because can further help in identifying training needs.

\section{Conclusion}

It can be expected that above mentioned investment plan on managing talent within the business organization can result in the attraction of large talented base for the participants of the financial institutions. Needs of training are highly crucial in the financial industry and those who have top cream talent of industry is successful in achieving the goals and objectives of the study. Additionally, qualitative investment plan as mentioned above can be helpful for the industry participants in making most of their investment in boosting the talent within their company. Strategies mentioned for investment plan of human capital management i.e. comprehensive learning 
through e-learning, experimental learning approach, performance measurement system, rewards and recognition and continuous monitoring of talent management framework are worthy of inviting expected returns from the cash invested by the management to manage their human capital. It is recommended to the finance companies to articulate their human resource policies in a new way $\mathrm{n}$ order to tackle with the shift in trends of talent management.

\section{References}

Baron, A., \& Armstrong, M. (2007). Human capital management: achieving added value through people. Kogan Page Publishers.

Condrey, S. E. (2010). Handbook of Human Resource Management in Government. John Wiley \& Sons.

Harris, C. M., McMahan, G. C., \& Wright, P. M. (2012). Talent and time together: The impact of human capital and overlapping tenure on unit performance. Personnel Review, 41(4), 408-427.

Höglund, M. (2012). Quid pro quo? Examining talent management through the lens of psychological contracts. Personnel Review, 41(2), 126-142.

Ingham, J. (2012). Strategic Human Capital Management. Routledge.

Management Accounting: Magazine for Chartered Management Accountants. (2000). How to introduce a performance management framework into your organisation. Management Accounting: Magazine for Chartered Management Accountants, 78(1).

People Management. (2009). Research topic: talent pools. People Management, 15(20), 32.

Pham-Gia, K. (2009). Talent Management: Recruitment Methodologies-an Overview. GRIN Verlag.

Shukla, R. (2009). TALENT MANAGEMENT: Process of Developing and Integrating Skilled Workers. Global India Publications.

Silzer, R., \& Dowell, B. E. (2009). Strategy-Driven Talent Management: A Leadership Imperative. John Wiley \& Sons.

Sreenivas, T. (2006). Banking Sector and Human Resources: Changing Scenario. Discovery Publishing House.

Syedain, H. (2010). Talent can be a dirty word. People Management, 18-21.

Thomson, R. (2007). Financial firms miss out on top IT talent, says recruiter. Computer Weekly, 50.

Ward, M. D. (2009). Human capital management: 2nd generation. Industrial and Commercial Training, 41(4), 212-214.

Warren, C. (2006). BANKING ON TALENT. People Management, 12(15), 32-34.

\section{Copyrights}

Copyright for this article is retained by the author(s), with first publication rights granted to the journal.

This is an open-access article distributed under the terms and conditions of the Creative Commons Attribution license (http://creativecommons.org/licenses/by/3.0/). 